\title{
The occurrence of accidents and injury in mining shift worker influenced by food intake, a short review
}

Gentil A. Andaque ${ }^{1}$, Olivia Pinho ${ }^{2}$, J. Santos Baptista ${ }^{3}$, J. Castelo Branco ${ }^{4}$, Elizabete Nunes ${ }^{5}$

\begin{abstract}
${ }^{1}$ Faculty of Engineering, University of Porto, PT (gentilandaque@gmail.com) ORCID 0000-0001-9882-8735, ${ }^{2}$ Associated Laboratory for Green Chemistry (LAQV/REQUIMTE), Faculty of Nutrition and Food Science, University of Porto, PT, (oliviapinho@fcna.up.pt) ORCID 0000-00019477-8638, ${ }^{3}$ Associated Laboratory for Energy, Transports and Aeronautics - LAETA (PROA), Faculty of Engineering, University of Porto, PT (jsbap@fe.up.pt) ORCID 0000-0002-8524-5503, ${ }^{4}$ Associated Laboratory for Energy, Transports and Aeronautics - LAETA (PROA), Faculty of Engineering, University of Porto, PT (jcb@fe.up.pt) ORCID 0000-0002-9254-4384, ${ }^{5}$ Faculty of Medicine, University Eduardo Mondlane, Moçambique (dra.elizabete.nunes@gmail.com) ORCID 0000-0002-1736-1473.

https://doi.org/10.24840/978-972-752-279-8_0065-0072
\end{abstract}

\begin{abstract}
Introduction: Identifying factors that contribute to occupational accidents has been a general concern of companies in the present millennium. One of the factors identified is the quality and quantity of food, as well as meals times. In this context, the present systematic review aimed to identify how food intake influences the occurrence of accidents in shift work, with some focus, although not exclusive, on the mining industry. Methodology: The research-based literature was carried out in four electronic databases: Medline/PubMed, Science Direct, Scopus and Web of Science. Have been combined the following words "occupational accident" and "food intake"; "mining injury" and "food choice"; "meal timing" and "workplace"; "eating at night" and "mining injury"; "Circadian rhythm" and "diet shift"; "Food safety" and " Health risk"; "workplace accidents" and "food choice". Results: It was possible to identify 24 articles related to food intake. To better understand the analysis, the results were organized into five groups: Author surname and year, Study type, Accidents/injury causes, risk factor, Conditions for accidents/injuries to occur. Through the groups of causes, it was possible to regrouped on three, which facilitated the discussion of the topic; food choice $n=10(42 \%)$ articles, eating habits $n=9(37.5 \%)$, and emotional commitment $n=5$ (20.5\%), showed the relativity of food intake causes for the occurrence of accidents and illnesses in shift workers. Discussion: The reviewed articles demonstrated that the materialisation of accidents was due to the relationship between food intake and consumption of nutrient-poor foods in shift work. That can develop chronic diseases, metabolic disorders such as blood pressure abnormalities, blood sugar fluctuation (dyslipidemia, dysglycemia), and obesity, neurobehavioural performance. Foods contain high content As, $\mathrm{Cd}, \mathrm{Cr}, \mathrm{Hg}, \mathrm{Fe}$, and $\mathrm{Mn}$ above the recommended standards by the FAO/WHO. Sleep disturbance during the 12-hour shift interferes with circadian rhythm and, consequently, with performance. These factors can be related to food and the precarious physical environment, increased workload, fatigue and poor diet, especially at night. Conclusion: In conclusion, the study demonstrated how food intake impacted workers' health on shifts but did not determine the causes or risk factors contributing to accidents/injuries. Further studies are needed to demonstrate a direct relationship which the risk factor of food intake and causes accidents/injuries.
\end{abstract}

Keywords: Food intake, Accidents, Shift work, Poor food.

\section{INTRODUCTION}

The reason that influences occupational accidents and diseases related to workplace food intake in workplaces is a fact to be explored. The causes that influence occupational accidents related to food intake have been demonstrated ( Stothard et al., 2020; Strzemecka et al., 2014; Geaney et al., 2016; Bonnell et al., 2017; Nea et al., 2018;). They are linked with factors such as shift work (Boivin \& Boudreau, 2014; Gupta et al., 2019; Heath et al., 2016; Reid, 2001;). The interaction of workplace food intake with other causes has adverse effects on the performance of activities, which in many cases can influence the occurrence of accidents and injures (Gifkins et al., 2018; Leung et al., 2010). The food intake in shift work has been considered responsible for the increase in body mass index (BMI) due to the imbalance of glycemia in the body (Di Lorenzo et al., 2003; Stothard et al., 2020), which has caused obesity problems, resulting from increased intake of snacks on a night shift and saturated fat diet (Heath et al., 2016)(Geaney et al., 2013). In addition, the first hours of the daily meal have adverse effects on ensuing processes of regulating worker chron-nutrition (Della Torre et al., 2020). Irregular food consumption interferes with the adjustment of insulin secretion (responsible for regulating the sugar in the organism needed for energy in the cells), which interferes with workers' performance ( Strzemecka et al., 2014; Gupta et al., 2019;). The insulin secretion in the body depends on dietary 
habits when taking a meal irregularly, which will influence the fluctuation of insulin production, which can compromise the metabolic process in the balance of nutrients in the body (Azmi et al., 2020; Heath et al., 2016).

Several research reports that the intake of food in shift workers influences the metabolic processes and has implications in work performance ( Arble et al., 2009; Lowden et al., 2010). In shift work, workers are subject to tiredness and stress associated with work activities, consequently more food intake than normal. This is worsened with an increase in the consumption of poor quality food. In general, poor foods do not have micronutrients and the regulated vitamins in the desirable properties for consumption; have high-level sugar, fat and sodium. In most cases, these low-quality food options are considered calorie-rich foods, which are nutritionally inadequate and contain more calories than nutrients like vitamins and minerals. ( Fletcher, 2010; Azmi et al., 2020 ).

In addition, more studies on the causes of accidents at work with food intake in the industries are necessary. It becomes a greater challenge when talking about mining (Nawab et al., 2016) since many studies refer to the effect of food intake in the vicinity of mines ( Zhuang et al., 2009; Bempah \& Ewusi, 2016; Huang et al., 2017; Rahmdel et al., 2018; Fitzgerald et al., 2018;).

The work in several industries, like mining, is many times subject to shift work. This short literature review (SLR) shows evidence of food influencing accidents in shift work. This possibility motivates the deepening of research on accidents at work-related food intake. Moreover, the SLR intends to answer the following question; how food intake influences accidents?

So, the purpose of this short review is to systematize articles that indicate how food intake can influence accidents or injury in shift work, with some focus, although not exclusive, on the mining industry.

\section{METHODOLOGY}

\section{Literature search strategy}

In proposing this review, priority was given to peer-reviewed journals in the area under study and published in scientific journals. The research-based literature was conducted in four electronic databases: MEDLINE / PubMed, Science Direct, Scopus, and Web of Science.

The screening of the articles was through the combination of several key terms, such: "occupational accident" and "food intake"; "mining injury" and "food choice"; "meal timing" and "workplace"; "eating at night" and "mining injury"; "Circadian rhythm" and "diet shift"; "Food safety" and "Health risk"; "workplace accidents" and "food choice". This short review is based on PRISMA Statement guidelines (Kirtley et al., 2021) shown below (figure1). 


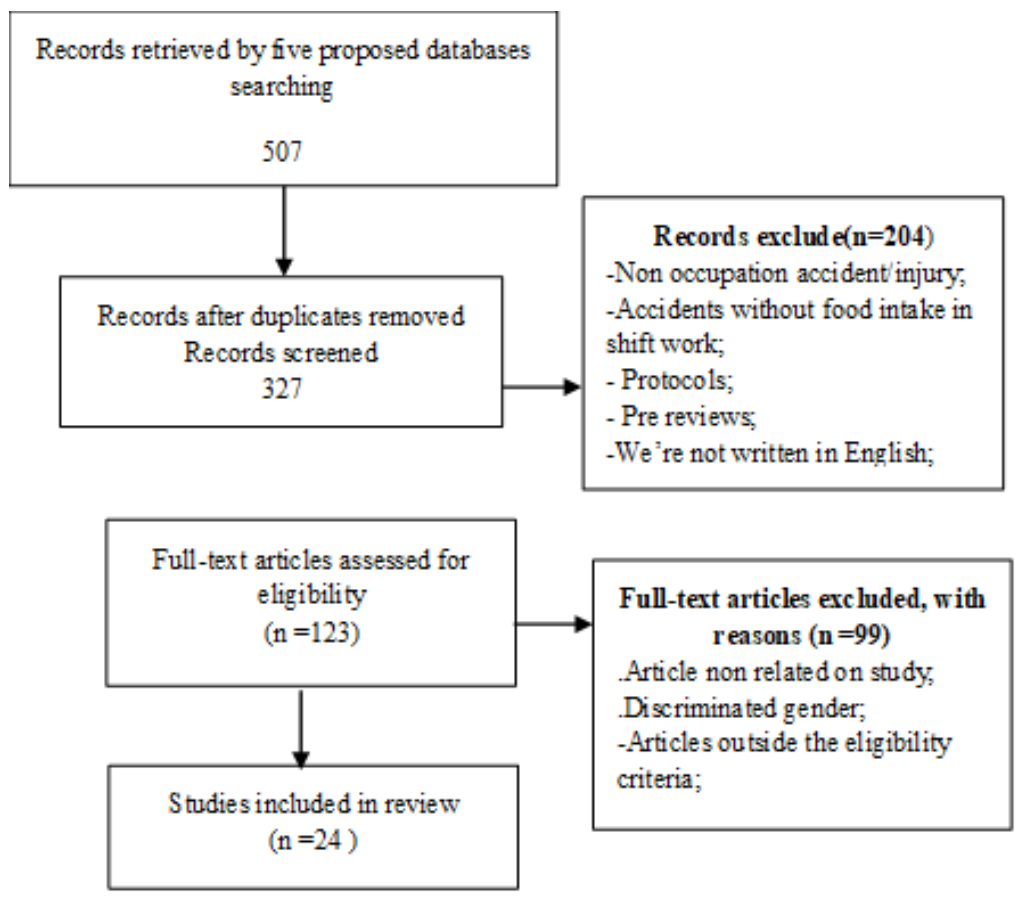

Figure 1. Flow chart illustrating the steps of literature selection.

\section{Eligibility criteria}

To inclusion and exclusion criteria based on review goals, i.e. systematize how food intake influences the accident or injury in mining shift work. Were included i) published journals articles, papers which refer impact of food intake in mining shift worker or related to it, ii) intervention and observation study with measures, iii) full text written in English. Were excluded from the review if; i) did not mention food intake at workplace on shift work, ii) not published, iii) does not meet eligibility criteria, iv) not full teste available, v) between 2000 and 2020.

\section{RESULTS}

\section{Data items/characteristics}

In order to provide an insight into how food intake influence on accidents or injuries in shift work, variables were designed with specific characteristics such as Surname of principal author $\&$ year, accident's or injury causes, risk factor, Conditions for accidents and injuries to occur in shift work that allowed the discussion.

\section{Food intake and accident/injury on shift work}

Findings of food intake reports in work shifts were obtained through a table organized by the author \& year, study types, causes, risk factors, and Conditions for accidents/injuries in shift work. The table 1 presents 24 articles, presents 24 articles, which analyze the causes of propensity to the occurrence of accidents/injury in the mines. They were organized according to the factors that interfere on this effect, such food choice $(n=10) 42 \%$; eating habits $(n=9)$ $37.5 \%$ and Emotional impairment $(n=5) 20.8 \%$. In general, studies report the effects of shift work as making regular meals consumption difficult (Strzemecka et al., 2014)

The systematization of the present articles through the screening of the possible causes of accidents allowed to identify the following risk factor: accidents influenced by behavioural impairment due to long working hours, after ingesting poor food, i.e. rich in sugar, fats devoid of essential micronutrients, developing chronic diseases like the development of metabolic 
disorders such as blood pressure abnormalities, blood sugar fluctuation (dyslipidemia, dysglycemia), and obesity, neurobehavioral performance, during shift work and particularly night work, creating changes in the circadian and behavioural cycle. Fatigue in the night-time, beginning of the first food intake from the day, all linked with greater emphasis on eating behaviour in shift work, were identified as the main conditions for accidents and injuries at work (Gupta et al., 2019 Azmi et al., 2020). Furthermore, in shift work in mines, there is high food consumption with a high content of heavy metals, e.g., water and vegetable intake above the standards established by various organizations such as FAO/WHO (Rahmdel et al., 2018).

Table 1. Study items/characteristics

\begin{tabular}{|c|c|c|c|c|}
\hline autor \& year & Study type & $\begin{array}{l}\text { Accidents/ } \\
\text { injury causes }\end{array}$ & Risk factor & $\begin{array}{l}\text { Conditions for accidents / injuries to } \\
\text { occur }\end{array}$ \\
\hline $\begin{array}{l}\text { Huang et al. } \\
2017\end{array}$ & $\begin{array}{l}\text { Prospective } \\
\text { cohort study }\end{array}$ & Food choice & $\begin{array}{l}\text { Intake vegetables with } \\
\text { high heavy metals }\end{array}$ & $\begin{array}{l}\text { The } \mathrm{Pb} \text { level exceeded the permissible } \\
\text { limit of } 0.3 \mathrm{mg} / \mathrm{kg} \text { in } 44.7 \% \text { of vegetable } \\
\text { samples according to FAO/WHO } \\
\text { standards }\end{array}$ \\
\hline $\begin{array}{l}\text { Zhuang et } \\
\text { al., } 2009\end{array}$ & $\begin{array}{l}\text { Prospective } \\
\text { cohort study }\end{array}$ & Food choice & $\begin{array}{l}\text { Drinking water \& vegetable } \\
\text { higher than permissible } \\
\text { limit standards }\end{array}$ & $\begin{array}{l}\text { Toxicity through to Drinking other and } \\
\text { consumption; }\end{array}$ \\
\hline $\begin{array}{l}\text { Rahmdel et } \\
\text { al., } 2018\end{array}$ & $\begin{array}{l}\text { Prospective } \\
\text { cohort study }\end{array}$ & Food choice & $\begin{array}{l}\text { Consumption of heavy } \\
\text { metals in food }\end{array}$ & $\begin{array}{l}\text { The target hazard quotient (THQ) for } \mathrm{Cd} \\
\& \mathrm{~Pb} \text { of rice and vegetables the average } \\
\text { is } 11 \% \text { daily intake exceeded the (PCL) of } \\
\text { FAO/WHO, }\end{array}$ \\
\hline $\begin{array}{l}\text { Nawab et } \\
\text { al., } 2016\end{array}$ & $\begin{array}{l}\text { Prospective } \\
\text { cohort study }\end{array}$ & $\begin{array}{l}\text { Emotional } \\
\text { impairment }\end{array}$ & $\begin{array}{l}\text { Accidents caused by } \\
\text { irregular working hours } \\
\text { and night work }\end{array}$ & $\begin{array}{l}\text { Combination of a higher workload, } \\
\text { fatigue and too little food night shift } \\
18 \% \text {; the fatigue and lack of } \\
\text { concentration, caused } 62 \text { critical } \\
\text { accidents are noted }\end{array}$ \\
\hline $\begin{array}{l}\text { Fletcher, } \\
2010\end{array}$ & $\begin{array}{l}\text { Descriptive } \\
\text { study }\end{array}$ & $\begin{array}{l}\text { Emotional } \\
\text { impairment }\end{array}$ & $\begin{array}{l}\text { Fatigue in the nighttime } \\
\text { sleep-night work }\end{array}$ & $\begin{array}{l}\text { Impairment Truck Drive } 30-40 \% \text { of } \\
\text { accidents occur in night shift work; } \\
\text { Human error } 30-50 \% \text { after a meal }\end{array}$ \\
\hline $\begin{array}{l}\text { Lowden et } \\
\text { al., } 2010\end{array}$ & descriptive study & Eating habits & Dietary habits; & $\begin{array}{l}\text { The type of food to be consumed during } \\
\text { shift duties was } 86 \% \text { overweight, } 66 \% \\
\text { obese; }\end{array}$ \\
\hline $\begin{array}{l}\text { Di Lorenzo } \\
\text { et al., } 2003\end{array}$ & $\begin{array}{l}\text { Prospective } \\
\text { cohort study }\end{array}$ & Eating habits & $\begin{array}{l}\text { Obesity has a greater } \\
\text { impact on work }\end{array}$ & $\begin{array}{l}\text { Prevalence of obesity in shift work was } \\
37 / 185=20 \% \text { than day worker } 9 / 134= \\
9,7 \%\end{array}$ \\
\hline $\begin{array}{l}\text { Geaney et } \\
\text { al., } 2013\end{array}$ & $\begin{array}{l}\text { Prospective } \\
\text { cohort study }\end{array}$ & $\begin{array}{l}\text { Emotional } \\
\text { impairment }\end{array}$ & Emotional Stress & Poor physical environment was $62.5 \%$ \\
\hline $\begin{array}{l}\text { Leung et al., } \\
2010\end{array}$ & descriptive study & Eating habits & $\begin{array}{l}\text { work overload, poor } \\
\text { physical environment }\end{array}$ & Injury incident \\
\hline $\begin{array}{l}\text { Gifkins et } \\
\text { al., } 2018\end{array}$ & $\begin{array}{l}\text { Retrospective } \\
\text { case-control }\end{array}$ & Eating habits & $\begin{array}{l}\text { Eating during the night } \\
\text { shift }\end{array}$ & $\begin{array}{l}\text { Shift work increases the fat meal and } \\
\text { snack was 38\% and } 56 \%\end{array}$ \\
\hline $\begin{array}{l}\text { Boivin \& } \\
\text { Boudreau, } \\
2014 \\
\end{array}$ & $\begin{array}{l}\text { Retrospective } \\
\text { case-control }\end{array}$ & Food choice & Shift work and sleep & $\begin{array}{l}\text { with fewer meals and more snacks a day; } \\
\text { causes tired drivers; }\end{array}$ \\
\hline $\begin{array}{l}\text { Heath et al., } \\
2016\end{array}$ & $\begin{array}{l}\text { prospective } \\
\text { cohort study }\end{array}$ & Food choice & $\begin{array}{l}\text { dietary profile in shift } \\
\text { workers and findings }\end{array}$ & $\begin{array}{l}\text { reduced sleep duration may result in } \\
\text { changes to fat, and potentially } \\
\text { carbohydrates, in the diet was compared } \\
\text { daily energy intake was (15-25)\% \& night } \\
(20-35) \% .\end{array}$ \\
\hline $\begin{array}{l}\text { Gupta et al., } \\
2019\end{array}$ & descriptive study & $\begin{array}{l}\text { Emotional } \\
\text { impairment }\end{array}$ & $\begin{array}{l}\text { Eating behaviour of shift } \\
\text { workers }\end{array}$ & $\begin{array}{l}\text { about } 50 \% \text { do not eat because of shift } \\
\text { work }\end{array}$ \\
\hline Reid, 2001 & $\begin{array}{l}\text { Prospective } \\
\text { cohort study }\end{array}$ & $\begin{array}{l}\text { Emotional } \\
\text { impairment }\end{array}$ & $\begin{array}{l}\text { Reductions in } \\
\text { neurobehavioral } \\
\text { performance in night work }\end{array}$ & $\begin{array}{l}\text { Sleep disruption during a } 12 \text {-hour shift; } \\
\text { circadian rotation rhythm of } \\
\text { performance-related a (food), comparing } \\
\text { two group's older \& young it is } 53 \% \text { \& } \\
24,5 \%\end{array}$ \\
\hline $\begin{array}{l}\text { Bonnell et } \\
\text { al., } 2017\end{array}$ & $\begin{array}{l}\text { Prospective } \\
\text { case-control }\end{array}$ & Food choice & $\begin{array}{l}\text { Food choice and dietary } \\
\text { intake }\end{array}$ & $\begin{array}{l}\text { night shift cooked meal was } 78 \% \text {, ice } \\
\text { creams, and chocolates, sweet pastries } \\
\text { were } 33 \% \text { than day shift } 48 \% \text { and } 23 \% \\
\text { respectively }\end{array}$ \\
\hline
\end{tabular}




\begin{tabular}{|c|c|c|c|c|}
\hline $\begin{array}{l}\text { Nea et al., } \\
2018\end{array}$ & $\begin{array}{l}\text { Prospective } \\
\text { cohort study }\end{array}$ & Eating habits & $\begin{array}{l}\text { Negatively impacting on } \\
\text { eating and lifestyle } \\
\text { behaviours }\end{array}$ & $\begin{array}{l}\text { Almost half ( } 48 \%) \text { were overweight or } \\
\text { obese } \& \text { while } 30 \% \text { were physically active } \\
\text { once or less weekly }\end{array}$ \\
\hline $\begin{array}{l}\text { Stothard et } \\
\text { al., } 2020\end{array}$ & $\begin{array}{l}\text { Prospective } \\
\text { cohort study }\end{array}$ & Eating habits & $\begin{array}{l}\text { Impact of food intake in } \\
\text { the early morning on } \\
\text { metabolism }\end{array}$ & $\begin{array}{l}\text { Glucose level 5\% higher was observed } \\
80 \text { min in shift workers compared to non- } \\
\text { shift workers; observed obesity and } \\
\text { diabetes that may be related to food } \\
\text { intake in the adverse circadian cycle }\end{array}$ \\
\hline $\begin{array}{l}\text { Strzemecka } \\
\text { et al., } 2014\end{array}$ & $\begin{array}{l}\text { Prospective } \\
\text { cohort study }\end{array}$ & Eating habits & Food in Shift worker & $\begin{array}{l}\text { About }(66.0 \%) \text { of workers admitted that } \\
\text { shift work hampers regular consumption } \\
\text { of meals. }\end{array}$ \\
\hline $\begin{array}{l}\text { Geaney et } \\
\text { al., } 2016\end{array}$ & $\begin{array}{l}\text { Prospective } \\
\text { cohort study }\end{array}$ & Food choice & Dietary intakes & $\begin{array}{l}\text { Employer improves nutrition program } \\
\text { reduction of } 32 \% \text { compared to those who } \\
\text { did not participate, which was } 78 \% \text {. }\end{array}$ \\
\hline $\begin{array}{l}\text { Fitzgerald et } \\
\text { al., } 2018\end{array}$ & $\begin{array}{l}\text { Prospective } \\
\text { case-control }\end{array}$ & Food choice & Food choice at work & $\begin{array}{l}\text { The incidence was observed at } 20 \% \text { of } \\
\text { obese }\end{array}$ \\
\hline $\begin{array}{l}\text { Della Torre } \\
\text { et al., } 2020\end{array}$ & $\begin{array}{l}\text { Prospective } \\
\text { cohort }\end{array}$ & Eating habits & $\begin{array}{l}\text { Shift work is associated } \\
\text { with an increased risk of } \\
\text { chronic diseases due to } \\
\text { circadian rhythm } \\
\text { disruptions and } \\
\text { behavioural changes }\end{array}$ & $\begin{array}{l}\text { About } 49 \% \text { were overweight, and } 13 \% \\
\text { were obese. Using } \\
\text { the percentage of body fat mass (BMI). }\end{array}$ \\
\hline $\begin{array}{l}\text { Bempah \& } \\
\text { Ewusi, } 2016\end{array}$ & $\begin{array}{l}\text { Prospective } \\
\text { cohort }\end{array}$ & Food choice & $\begin{array}{l}\text { Foods containing high } \\
\text { content } \mathrm{As}, \mathrm{Cd}, \mathrm{Cr}, \mathrm{Hg}, \mathrm{Fe}, \\
\text { and } \mathrm{Mn} \text { above the allowed } \\
\text { standards }\end{array}$ & $\begin{array}{l}\text { Analytical procedures were verified by } \\
\text { suitable certified reference materials } \\
\text { (CRMs) and an average of } 10 \% \text { of the } \\
\text { certified value. }\end{array}$ \\
\hline $\begin{array}{l}\text { Azmi et al., } \\
2020\end{array}$ & $\begin{array}{l}\text { Descriptive } \\
\text { study }\end{array}$ & Eating habits & $\begin{array}{l}\text { Development of metabolic } \\
\text { disorders such as } \\
\text { hypertension, } \\
\text { dyslipidemia, dysglycemia, } \\
\text { and abdominal obesity }\end{array}$ & $\begin{array}{l}\text { Metabolic syndrome, Cardiovascular } \\
\text { disease, Gastrointestinal disorders, } \\
\text { Breast cancer, Psychological disorder }\end{array}$ \\
\hline $\begin{array}{l}\text { Arble et al., } \\
2009\end{array}$ & $\begin{array}{l}\text { Prospective } \\
\text { Cohort stud }\end{array}$ & Food choice & $\begin{array}{l}\text { The circadian phase of } \\
\text { food consumption in } \\
\text { weight gain }\end{array}$ & $\begin{array}{l}\text { There was calorie consumption in }(80 \%) \\
\text { during the dark phase (night) in relation } \\
\text { to the light phase (day). }\end{array}$ \\
\hline
\end{tabular}

The research demonstrates the evidence of food intake in relation to the accidents/injury in the shift work. There are factors such as higher workload, fatigue, bioaccumulation of heavy metals in food content $\mathrm{As}, \mathrm{Cd}, \mathrm{Cr}, \mathrm{Hg}, \mathrm{Fe}$, and $\mathrm{Mn}$; percentage of body fat mass was higher than average compared with non-shift workers, in an expressive number among workers; was observed potentially carbohydrate in night shift than the day. Therefore, shift work is considered to have a higher impact on the diet. Shift work is a service preferred in many industries because it accelerates the workforce's production and flexibility to optimize productivity and business in competitive companies.

\section{DISCUSSION}

Accidents and injuries have been addressed in various themes. The convergence is that there must be causes, risk factors, and conditions necessary for the occurrence in all cases. In this review, these variables were demonstrated concerning food intake in shift work. There are about $42 \%$ of studies, the causes of the accidents are related to the food choice at night shifts that have higher calorie consumption than during the day Arble et al.,( 2009). Night shifts have a higher consumption of cooked meal, ice cream, chocolates, sweets pastries than the day Bonnell et al., (2017), higher incidence of obesity in workers assigned to shift work than regular work (Fitzgerald et al., 2018). If the mining activity considered dangerous, then it needs a lot of attention in the execution. It was demonstrated that eating foods with a low micronutrient content affects workers' performance. The choice of food for workers must be the companies' responsibility and preparation to safeguard the nutritional demand needed for the job. That increase sleep, fatigue, stress, blood pressure abnormalities and sugar fluctuation. So the food choice in this activity has to be enhanced. Foods in shift work affect about 15 to $30 \%$ of adults in the European population (Boivin \& Boudreau, 2014). Most mining works are carried out in 
areas other than the habitual residence of workers. Many of them take their food. This possibility makes them buy local food, can put in cause their health since, in the mining areas food, the water consumed has verified the bioaccumulation of heavy metals as $\mathrm{As}, \mathrm{Cd}, \mathrm{Cr}, \mathrm{Hg}$, $\mathrm{Fe}$, and $\mathrm{Mn}$, which is not acceptable for human consumption according to FAO/ WHO (Zhuang et al., 2009; Bempah \& Ewusi, 2016; Huang et al. 2017 Rahmdel et al., 2018). Food choice can be a significant factor for the performance of daily activities influencing accidents/injuries in workplaces.

Other causes of accident in the systematic review were linked with eating habits at $37.5 \%$ in all articles. Eating habits are associated with the consumption behaviour of certain foods in shift work. Evidence shows that there are workers who consume more food and, on the other hand, those who have difficulties in feeding, this associated body mass index (BIM) regardless of age and duration of work (Di Lorenzo et al., 2003; Gupta et al.,2019). Consequently, cardiovascular disease, Gastrointestinal disorders, Breast cancer, Psychological disorder, i.e. development of chronic diseases affect a relatively young population, conditions put debilitated worker minded to accidents and injuries (Azmi et al., 2020; Nea et al., 2018; Della Torre et al., 2020). Eating habits also influenced by circadian rhythms, the process by which every man needs to adjust every 24 hours, which has been greatly affected by shift work in the process of food intake. What impacts work performance due to the quality of rest and meals during this work period (Leung et al., 2010; Gifkins et al., (2018).

Likewise, emotional impairment was the accident causes related a food intake, there correspond $20.8 \%$ of studies, to the extent that it contributed to the commitment of shift work specifically night work caused sleep disruption during a 12-hour shift; circadian rotation rhythm of performance-related a (food) (Reid, 2001). What influenced the emotional behaviour of the shift work in food intake is also noted the difficulties in their regular consumption (Gupta et al., 2019). These conditions associated with stress due to the difficulty in food intake created a working environment impacted $62.5 \%$ of work performance (Geaney et al., 2013). Consequently, necessary conditions were formed to the occurrence of occupational accidents. Irregular and nocturnal schedules and increased workload, tiredness and little nighttime feeding were responsible for 62 critical accidents in mines resulting from fatigue and lack of concentration (Nawab et al., 2016).

\section{CONCLUSIONS}

In a nutshell, the present systematic literature review (SLR) aimed to systematize articles indicating how food intake can influence accidents or injury in shift work. Were extracted 24 articles eligible for the present study from four databases. The SLR reveals that food intake in shift work has numerous impacts on the health and well-being of workers, mainly in the ingestion of foods with low macronutrients associated with inadequate daily rest. Responsible for development of chronic diseases in workplace, their effect can impact the ability to perform daily tasks. Features like; food choice, food habits and emotional commitment were crucial in establishing the relationship. Specific study in mines related to food intake with accidents and injuries in shift work in the industry are scarce. The few that exist are inconclusive. Further studies are needed to demonstrate a direct relationship which the risk factor of food intake and causes accidents/injuries.

\section{References}

Azmi, N. A. S. M., Juliana, N., Teng, N. I. M. F., Azmani, S., Das, S., \& Effendy, N. (2020). Consequences of circadian disruption in shift workers on Chrono nutrition and their psychosocial well-being. International Journal of Environmental Research and Public Health, 17(6). https://doi.org/10.3390/ijerph17062043

Bempah, C. K., \& Ewusi, A. (2016). Heavy metals contamination and human health risk assessment around Obuasi gold mine in Ghana. Environmental Monitoring and Assessment, 188(5). https://doi.org/10.1007/s10661-0165241-3 
Boivin, D. B., \& Boudreau, P. (2014). Impacts of shift work on sleep and circadian rhythms. In Pathologie Biologie (Vol. 62, Issue 5, pp. 292-301). Elsevier Masson SAS. https://doi.org/10.1016/j.patbio.2014.08.001

Bonnell, E. K., Huggins, C. E., Huggins, C. T., McCaffrey, T. A., Palermo, C., \& Bonham, M. P. (2017). Influences on dietary choices during day versus night shift in shift workers: A mixed methods study. Nutrients, 9(3). https://doi.org/10.3390/nu9030193

Della Torre, S. B., Wild, P., Dorribo, V., Danuser, B., \& Amati, F. (2020). Energy, nutrient and food intakes of male shift workers vary according to the schedule type but not the number of nights worked. Nutrients, 12(4). https://doi.org/10.3390/nu12040919

Di Lorenzo, L., De Pergola, G., Zocchetti, C., L’Abbate, N., Basso, A., Pannacciulli, N., Cignarelli, M., Giorgino, R., \& Soleo, L. (2003). Effect of shift work on body mass index: Results of a study performed in 319 glucose-tolerant men working in a Southern Italian industry. International Journal of Obesity, 27(11), 1353-1358. https://doi.org/10.1038/sj.ijo.0802419

Fitzgerald, S., Murphy, A., Kirby, A., Geaney, F., \& Perry, I. J. (2018). Cost-effectiveness of a complex workplace dietary intervention: An economic evaluation of the Food Choice at Work study. BMJ Open, 8(3). https://doi.org/10.1136/bmjopen-2017-019182

Fletcher, A. (2010). Staying safe in the jungles of borneo: Five studies of fatigue and cultural issues in remote mining projects. Industrial Health, 48(4), 406-415. https://doi.org/10.2486/indhealth.MSSW-04

Geaney, F., Kelly, C., Di Marrazzo, J. S., Harrington, J. M., Fitzgerald, A. P., Greiner, B. A., \& Perry, I. J. (2016). The effect of complex workplace dietary interventions on employees' dietary intakes, nutrition knowledge and health status: A cluster controlled trial. Preventive Medicine, 89, 76-83. https://doi.org/10.1016/j.ypmed.2016.05.005

Geaney, F., Scotto Di Marrazzo, J., Kelly, C., Fitzgerald, A. P., Harrington, J. M., Kirby, A., McKenzie, K., Greiner, B., \& Perry, I. J. (2013). The food choice at work study: Effectiveness of complex workplace dietary interventions on dietary behaviours and diet-related disease risk - study protocol for a clustered controlled trial. Trials, 14(1). https://doi.org/10.1186/1745-6215-14-370

Gifkins, J., Johnston, A., \& Loudoun, R. (2018). The impact of shift work on eating patterns and self-care strategies utilised by experienced and inexperienced nurses. Chronobiology International, 35(6), 811-820. https://doi.org/10.1080/07420528.2018.1466790

Gupta, C. C., Coates, A. M., Dorrian, J., \& Banks, S. (2019). The factors influencing the eating behaviour of shiftworkers: What, when, where and why. In Industrial Health (Vol. 57, Issue 4, pp. 419-453). National Institute of Industrial Health. https://doi.org/10.2486/indhealth.2018-0147

Heath, G., Coates, A., Sargent, C., \& Dorrian, J. (2016). Sleep duration and chronic fatigue are differently associated with the dietary profile of shift workers. Nutrients, 8(12). https://doi.org/10.3390/nu8120771

Huang, Y., He, C., Shen, C., Guo, J., Mubeen, S., Yuan, J., \& Yang, Z. (2017). Toxicity of cadmium and its health risks from leafy vegetable consumption. Food and Function, 8(4), 1373-1401. https://doi.org/10.1039/c6fo01580h

Leung, M. Y., Chan, Y. S., \& Yuen, K. W. (2010). Impacts of stressors and stress on the injury incidents of construction workers in Hong Kong. Journal of Construction Engineering and Management, 136(10), 1093-1103. https://doi.org/10.1061/(ASCE)CO.1943-7862.0000216

Lowden, A., Moreno, C., Holmbäck, U., Lennernäs, M., \& Tucker, P. (2010). Eating and shift work - Effects on habits, metabolism, and performance. In Scandinavian Journal of Work, Environment and Health (Vol. 36, Issue 2, pp. 150-162). Nordic Association of Occupational Safety and Health. https://doi.org/10.5271/sjweh.2898

Nawab, J., Li, G., Khan, S., Sher, H., Aamir, M., Shamshad, I., Khan, A., \& Khan, M. A. (2016). Health risk assessment from contaminated foodstuffs: a field study in chromite mining-affected areas northern Pakistan. Environmental Science and Pollution Research, 23(12), 12227-12236. https://doi.org/10.1007/s11356-0166379-9

Nea, F. M., Pourshahidi, L. K., Kearney, J. M., Livingstone, M. B. E., Bassul, C., \& Corish, C. A. (2018). A qualitative exploration of the shift work experience: the perceived effect on eating habits, lifestyle behaviours and psychosocial well-being. Journal of Public Health (Oxford, England), 40(4), e482-e492. https://doi.org/10.1093/pubmed/fdy047

Persson, M., \& Mårtensson, J. (2006). Situations influencing habits in diet and exercise among nurses working night shift. Journal of Nursing Management, 14(5), 414-423. https://doi.org/10.1111/j.1365-2934.2006.00601.x 
Rahmdel, S., Rezaei, M., Ekhlasi, J., Hossein Zarei, S., Akhlaghi, M., Maryam Abdollahzadeh, S., Sefidkar, R., \& Mohammad Mazloomi, S. (2018). Heavy metals ( $\mathrm{Pb}, \mathrm{Cd}, \mathrm{Cu}, \mathrm{Zn}, \mathrm{Ni}, \mathrm{Co}$ ) in leafy vegetables collected from production sites: their potential health risk to the general population in Shiraz, Iran. https://doi.org/10.1007/s10661-018-7042-3

Reid, K. (2001). Comparing performance on a simulated 12 hour shift rotation in young and older subjects. Occupational and Environmental Medicine, 58(1), 58-62. https://doi.org/10.1136/oem.58.1.58

Seychell, J., \& Reeves, S. (2017). The effect of shift work on the diet of accident and emergency nurses at a general hospital in Malta. Nutrition and Food Science, 47(2), 165-174. https://doi.org/10.1108/NFS-05-2016-0059

Stothard, E. R., Ritchie, H. K., Birks, B. R., Eckel, R. H., Higgins, J., Melanson, E. L., Wright, K. P., \& McHill, A. W. (2020). Early morning food intake as a risk factor for metabolic dysregulation. Nutrients, 12(3). https://doi.org/10.3390/nu12030756

Strzemecka, J., Bojar, I., Strzemecka, E., \& Owoc, A. (2014). Dietary habits among persons hired on shift work. Annals of Agricultural and Environmental Medicine, 21(1), 128-131.

Zhuang, P., McBride, M. B., Xia, H., Li, N., \& Li, Z. (2009). Health risk from heavy metals via consumption of food crops in the vicinity of Dabaoshan mine, South China. Science of the Total Environment, 407(5), 1551-1561. https://doi.org/10.1016/j.scitotenv.2008.10.061 